\title{
Losses in water distribution networks - a bibliometric review: general aspects and
}

\section{optimization}

\author{
Perdas em redes de distribuiç̧ão de água - uma revisão bibliográfica: aspectos gerais e otimização \\ Pérdidas em las redes de distribución de agua - una revisión bibliométrica: aspectos generales y \\ optimización
}

\author{
Emerson Pessanha de Almeida \\ ORCID: https://orcid.org/0000-0002-7471-5370 \\ Universidade Federal de Itajubá, Brazil \\ E-mail: emerson.almeida@unifei.edu.br \\ Fernando das Graças Braga da Silva \\ ORCID: https://orcid.org/0000-0002-3803-2257 \\ Universidade Federal de Itajubá, Brazil \\ E-mail: ffbraga.silva@gmail.com \\ Victor Eduardo de Mello Valério \\ ORCID: https://orcid.org/0000-0003-4127-5951 \\ Universidade Federal de Itajubá, Brazil \\ E-mail: victor.dmv@unifei.edu.br
}

\begin{abstract}
The research carried out in the water distribution networks is of great importance, given the social, environmental and economic impacts that have occurred due to the scarcity of water resources. Therefore, any scientific effort shown in research that studies water distribution systems is of great relevance. Techniques such as mathematical modeling, computer simulation and statistical methods are widely used in order to obtain more reliable answers, whether for the identification of the current situation of the network, as well as for the prediction of scenarios, failure events, increased demand, etc. The objective of this work is to carry out a bibliometric analysis to identify the state of the art of research that addresses the theme of water distribution networks for the control and reduction of the volume of water losses, which will serve as a guide for future works to to structure itself in the most relevant researches that study the theme. The developed methodology was able to analyze a metadata composed of 4188 documents taken from the Web of Science journals database. As a result, a geographical view of the theme was obtained, pointing out the main countries, affiliations, journals and researchers, as well as pointing out the main documents and relevance of the theme. It can be concluded after the results obtained that bibliometric analysis is an important tool for obtaining the state of the art. With it is possible to have a better understanding of the current situation in the development of research, familiarizing researchers with what is most current and relevant.
\end{abstract}

Keywords: Water distribution networks; Water losses; Water loss control; Leakage water.

\section{Resumo}

As pesquisas realizadas nas redes de distribuição de água são de grande importância, dados os impactos sociais, ambientais e econômicos que têm ocorrido devido à escassez de recursos hídricos. Portanto, qualquer esforço científico denotado em pesquisas que estudem sistemas de distribuição de água é de grande relevância. Técnicas como modelagem matemática, simulação computacional e métodos estatísticos são amplamente utilizadas a fim de obter respostas mais confiáveis, seja para a identificação da situação atual da rede, como também para a previsão de cenários, eventos de falha, aumento de demanda, etc. $\mathrm{O}$ objetivo deste trabalho é realizar uma análise bibliométrica para identificar o estado da arte das pesquisas que abordam o tema redes de distribuição de água para o controle e redução do volume de perdas de água, que servirá de guia para futuros trabalhos os estruturando nas pesquisas mais relevantes que estudam o tema. A metodologia desenvolvida foi capaz de analisar um metadado composto por 4.188 documentos retirados da base de dados de periódicos da Web of Science. Como resultado, obteve-se uma visão geográfica do tema, apontando os principais países, afiliações, periódicos e pesquisadores, bem como apresenta os principais documentos e a relevância do tema. Pode-se concluir após os resultados obtidos que a análise bibliométrica é uma ferramenta importante para a obtenção do estado da arte. Com ela é possível ter um melhor entendimento da situação atual no desenvolvimento da pesquisa, familiarizando os pesquisadores com o que há de mais atual e relevante.

Palavras-chave: Redes de distribuição de água; Perdas de água; Controle de perdas de água; Vazamento de água. 


\section{Resumen}

Las investigaciones que se realizan sobre las redes de distribución de agua son de gran importancia, dados los impactos sociales, ambientales y económicos que se han producido por la escasez de recursos hídricos. Por lo tanto, cualquier esfuerzo científico denotado en investigaciones que estudien los sistemas de distribución de agua es sumamente relevante. Técnicas como modelización matemática, simulación por ordenador y métodos estadísticos son ampliamente utilizados con el fin de obtener respuestas más confiables, ya sea para identificar la situación actual de la red, así como para predecir escenarios, eventos de falla, aumento de la demanda, etc. El objetivo de este trabajo es realizar un análisis bibliométrico para identificar el estado del arte de la investigación que aborda el tema de las redes de distribución de agua para el control y reducción del volumen de pérdidas de agua, que servirá de guía para trabajos futuros. estructurándolos en las investigaciones más relevantes que estudien el tema. La metodología desarrollada fue capaz de analizar un metadato compuesto por 4.188 documentos extraídos de la base de datos de revistas de Web of Science. Como resultado, se obtuvo una visión geográfica del tema, señalando los principales países, afiliados, revistas e investigadores, además de presentar los principales documentos y la relevancia del tema. Se puede concluir luego de los resultados obtenidos que el análisis bibliométrico es una herramienta importante para obtener el estado del arte. Con él, es posible tener una mejor comprensión de la situación actual en el desarrollo de la investigación, familiarizando a los investigadores con lo más actual y relevante.

Palabras clave: Redes de distribución de agua; Pérdidas de agua; Control de pérdidas de agua; Gotera de agua.

\section{Introduction}

The existence of human life is connected to water consumption. Actions aimed the rational use of this resource, therefore, are required, considering its finiteness and an increasingly evolving demand linked to population growth (Shekofteh, et al., 2020).

For human consumption, water needs to have features that enable its use and, after necessary treatment, its supply to the population occurs from distribution networks in several forms, having in mind that the most usual of them works through the action of gravity. Water distribution systems need to meet regulatory requirements regarding potability, impermeability and pressure levels (Kerwin \& Adey, 2020).

Due to the complexity of the water supply to the population, usually associated with poor management, geographical challenges, or even assaults, several failures arise in treated water distribution systems. Regarding this, it becomes useful to provide researchers and decision makers involved in the topic an overview of the scientific development in the area (Liu \& Lansey, 2020). According to (Shamseer, et al., 2015) systematic's reviews are of great importance as they point to the future for researches themes addressed by the method.

Thus, the present research has, as general aim, to perform precisely a bibliometric analysis with the purpose of presenting the state of the art about the topic of water distribution networks.

In association, the general aim was structured considering the following specific aims:

- Collect data from authors, documents, journals, affiliations, countries and themes in the scientific journal base Web of science (WOS);

- Process and handle the imported metadata;

- Calculate the bibliometric indicators to analyze collected data (authors, documents, journals, affiliations, countries and themes);

- Analyze the measured bibliometric indicators.

It must be emphasized that technological advances and the expressive increase concerning the amount of research performed requires more than the experience of the researcher to structure systematic reviews on a given research theme. In this sense, the adoption of quantitative analysis of the production of a given area, based on bibliometric indicators, is gaining more and more space as it expands the possibility of providing an overview of a theme (Aria \& Cuccullo, 2017). 


\section{Methodology}

The bibliometric analysis structured as a research method was organized in a segmented structure adapted from the PRISMA-P method respecting its protocols and constituted of 3 steps, "Data import", "Data transformation" and "Data modelling and mapping", the organization chart presented in Figure 1 represents the respective ones.

Figure 1 - Flow chart showing data collection, modelling and mapping.

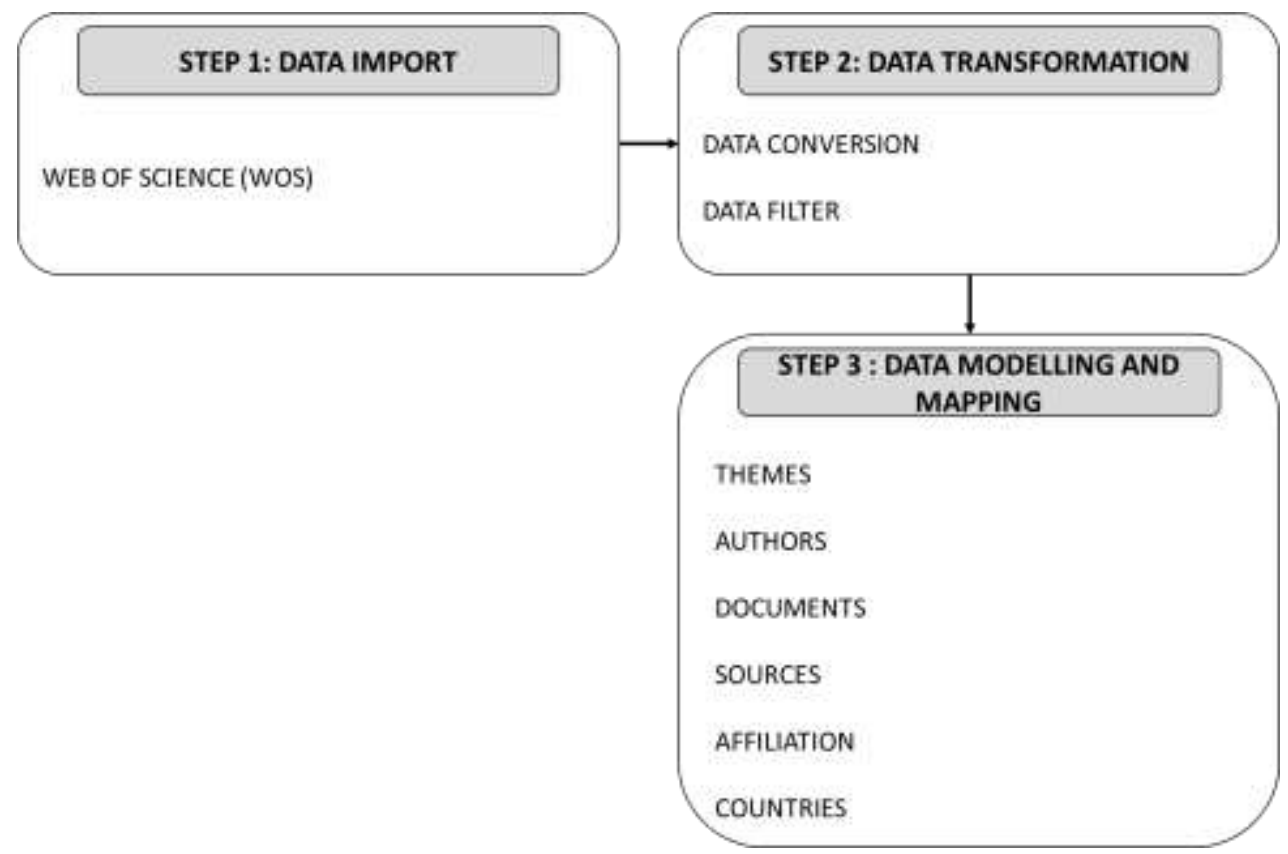

Source: Authors.

At the stage 1, the focus was on locating documents concerning water distribution networks. To obtain these documents, it was used The Web of Science, one of the largest journal query database. As descriptors of the theme the keywords used were: "Water distribution networks", "Water losses", "Water loss control" and "Leakage water".

Initially, the metadata was obtained from each of the journals bases without applying any kind of filter. Considering this, the samples of documents were initially composed of several types of documents, articles, books, book chapters, congresses and congress papers, among other documents; along with such sources, all the information available about the obtained documents as a result of the search was used, that is, bibliographical information, abstracts, quotes information, keywords and other information.

The second stage is initiated from the import of the samples with the metadata obtained from the WOS base, in plain text format, to the $\mathrm{R}$ software for the purpose of implementing treatment and analysis. It is important to highlight that the opensource programming language $\mathrm{R}$ is widely used in statistics, and has tools for implementing bibliometric analysis, from the Bibliometrix package (Aria \& Cuccullo, 2017). The import occurred by applying the convert2df function.

Still regarding the second stage: as a result of the previous process, a single matrix was organized in which the columns are segmented by different information about the documents, arranged in rows. Its access is available in the supplementary material of this article.

As the last process of the stage 2, a filter was applied so that the matrix was composed only by articles written in the English language. This filter is necessary because it allows the standardization of citations and encoding, which in turn makes possible the calculations of the bibliometric indicators related to the next stage of the research method. A last filter was applied in this stage and it is limiting the final publication period of the articles to the year 2020, which is the last complete year until 
the date of implementation of the present research. For the application of such, functions from the Dplyr package (Wickham, et al., 2021) were used.

Thus, the end of the second stage corresponds to the final matrix, containing the metadata of all articles from the base. It allows subsequent implementation of calculation and analysis of bibliometric indicators and corresponds to stage 3 of the research method. An overview of the organized sample of articles is presented in Table 1.

Table 1 - Metadata data.

\begin{tabular}{ll} 
Description & Results \\
\hline Timespan & $1946: 2020$ \\
Sources (Journals, Books, etc) & 1,071 \\
Documents & 4,188 \\
Average years from publication & 10.1 \\
Average citations per documents & 22.06 \\
Average citations per year per doc & 2.07 \\
References & 101,046 \\
Keywords Plus (ID) & 6,791 \\
Author's Keywords (DE) & 8,954 \\
Authors & 10,950 \\
Authors of single-authored documents & 213 \\
Authors of multi-authored documents & 10,737 \\
Single-authored documents & 241 \\
Documents per Author & 0.38 \\
Authors per Document & 2.61 \\
Collaboration Index & 2.72
\end{tabular}

Source: Authors.

Between the years 1946 and 2020 a total of 4,188 articles were published in 1,071 different journals. It can be seen from the sample that an article on water distribution networks is cited, on average, during 10.1 representing relatively low speed of scientific advancement. In turn, the average incidence of citations of each article and the annual citations per article are 22.06 and 2.06 respectively.

The sum of all the different references used by the articles that make up the sample is 101.046, with an average of 24.13 references per developed research. It is possible to infer that water distribution networks is a subject approached from a wide range of perspectives, due to the expressive amount of different keywords plus the author's keywords used, 6,791 and 8,954 , respectively.

A total of 10,950 authors were identified. From such amount, 213 authors conducted research without co-authorship, generating a volume of 241 articles. Therefore, the articles with co-authorship consist of an amount of 3,947 documents, equivalent to a collaboration index of 2.72 authors per published article.

Finally, the last stage of the proposed research method corresponds to modeling and mapping the sample based on bibliometric indicators, with the purpose of presenting the state of the art. In the present work, the various bibliometric indicators implemented were grouped into different analysis approaches and presented in order of increasing comprehensiveness. Firstly, from the author's keywords, the Thematic Map techniques (cobbo) were implemented with the purpose of identifying the research themes that are central and with greater density. In a complementary manner, the 
frequencies of author's keywords over time were also analyzed, also as a proxy of the advancement of the most worked on themes nowadays.

Subsequently, the authors in the area are estimated both for productivity and impact criteria. For the productivity analysis, an overview was started from the analysis of the distribution of publications by Lotka (Lotka); the amount of publications and the amount of publications divided by the amount of authors of each publication were also calculated. These last two productivity metrics were calculated only for the authors with the highest research impact, measured by that of the authors with the highest H-Index and, in a complementary manner to the impact analysis, the amount of local citations by each of the selected authors were also calculated, that is, the amount of citations that the authors received from other 4,188 authors in the selected sample, as a proxy for citations from the authors necessarily from the same area.

Next, the articles with the greatest impact in the area are estimated. In this case, it was used as an impact criterion the amount of local citations and, in a similar way, the amount of citations that the articles received from the other 4,188 articles in the selected sample, as a proxy of relevance within the theme. In a complementary manner, the total amount of citations the articles received is also presented.

At the same time, the most relevant sources for the area are estimated by the impact criterion of the respective publications. For this, once again the H-Index of each journal was used as an impact criterion. Next, the amount of publications of each journal over time is presented.

Finally, the contribution of the authors' affiliations and countries, based on the amount of publications as a proxy for productivity. Considering the countries, an evaluation of international collaboration is also added based on the measurement of the amount of articles with authors from multiple countries.

All the bibliometric indicators described above were implemented from functions of the R bibliometrix package (Aria \& Cuccullo, 2017).

\section{Results and Discussion}

\subsection{Conceptual Structure Analysis}

The thematic map presented in Figure 2 is a qualitative analysis that demonstrates the relevance of the themes addressed. In the upper right quadrant are found the most central and most dense themes considered as the driving themes of the research. The upper left quadrant points to less central and denser themes, where very specific research is conducted with little production volume. The lower left quadrant points to the less central and less dense themes, which are very common and with little relevance themes. Finally, the lower right quadrant shows themes that are very central but not very dense; these are common themes in which there is a large volume of publications due to the simplicity of the theme. 
Figure 2 - Thematic Map.

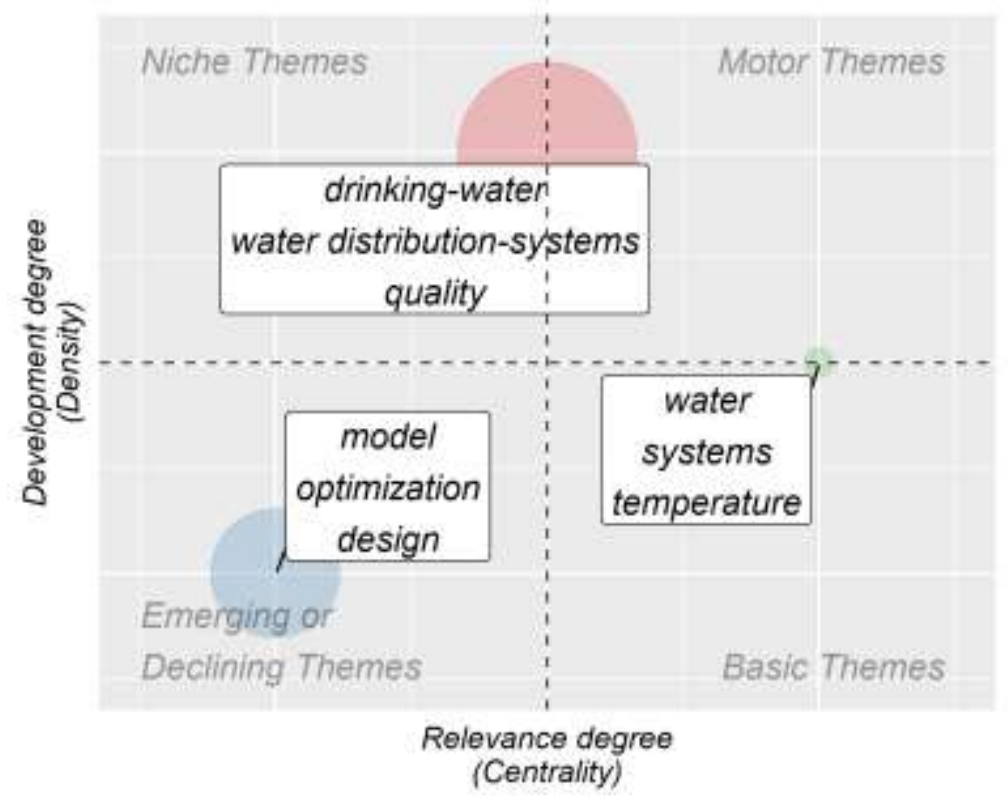

Source: Authors.

\subsection{Authors' keywords for Word growth generation.}

Figure 3 presents the development of the theme according to the keywords by the authors from the year 1990. These are themes that focus on water distribution networks such as management, design, model and optimization, which mostly aim at a more efficient control of the system, searching a balance between system resilience and operational cost. Drinking-water and water, on the other hand, are generally linked to potability research. Other themes are used for the description of the research. It is interesting to note that all themes have their development lines, with an exponential growth rate, with no indication of a turning point.

Figure 3 - Word growth.

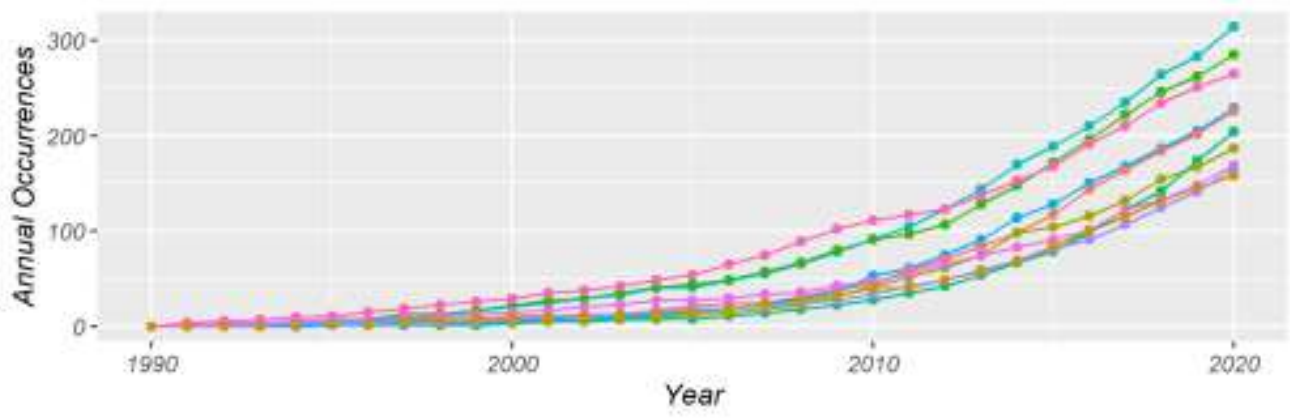

Words

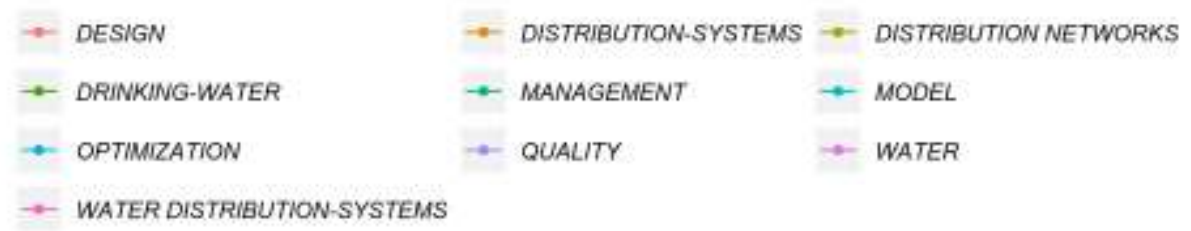

Source: Authors. 


\subsection{Authors Analysis}

First, in order to have an overview of the authors' productivity in this field of study, it was estimated the adjustment to lotka's law.

Figure 4 - Scientific Productivity.

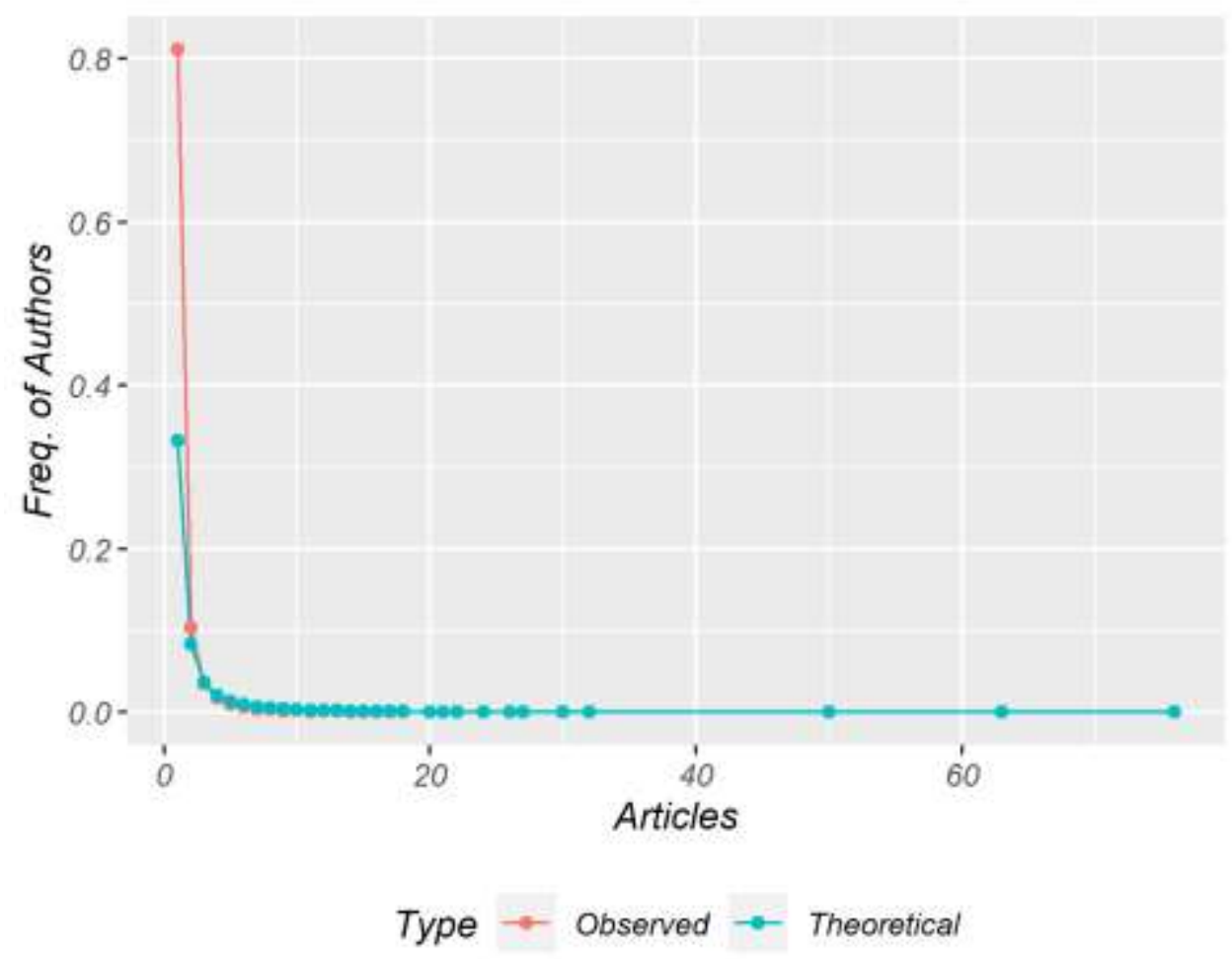

Source: Authors.

By applying the Kolmogorov-Smirnoff two-sample test, a p-value of 0.12 was calculated, confirming that there is no significant difference between the observed and theoretical distributions by Lotka.

As a way of measuring the scientific production of researchers, the h-index created by (Hirsch, 2005) is applied. Table 2 identifies the top ten authors according to the h-index, the total amount of published articles, the proportion of fractionalized Documents, which is basically the percentage of participation of a researcher in each published article and the total amount of local citations that are received by researchers in related fields. It is worth mentioning that, in some criteria, the order of authors could be different, however, the h-index is the most widely accepted among the scientific community. 
Table 2 - The top ten Authors.

\begin{tabular}{lllll} 
Authors & H_Index & Documents & Documents_fractionalized & Local Citations \\
\hline OSTFELD A & 27 & 76 & 31.27 & 849 \\
SIMPSON AR & 25 & 63 & 17.48 & 762 \\
KAPELAN Z & 22 & 50 & 12.93 & 533 \\
BOXALL JB & 17 & 32 & 9.41 & 370 \\
ZECCHIN AC & 19 & 30 & 6.75 & 292 \\
MAIER HR & 20 & 27 & 7.12 & 378 \\
SAVIC D & 16 & 27 & 5.59 & 385 \\
SAVIC DA & 16 & 26 & 7.83 & 323 \\
FRANCHINI M & 16 & 24 & 7.51 & 182 \\
KIM JH & 8 & 24 & 6.91 & 106
\end{tabular}

Source: Authors.

\subsection{Documents analysis}

The Table 3 arranges the top 10 articles according to local citation. It is interesting to note the year of accomplishment of each of the top 10 cited research that has 1977 as the oldest and 2013 as the most recente year. The research developed by (Alperovits, 1977) aims to optimize the water distribution system, as well as (Prasad, 2004), (Simpson, 1994), (Dandy, 1996), (Maier, 2003), (Araujo, 2006) and (Ostfeld, 2008), who used the genetic algorithm in its most diversified variations to achieve the proposed optimization objective. These are not contemporary researches, but they are until today one of the main researches related to the subject of optimization in water distribution networks, being the researches with the highest amounts of local citations received. Considering the most recent research conducted by (Ostfeld, 2004), it addresses the issue of water potability as well as (Rossman, 1994) and (Ostfeld, 2004). 
Table 3 - The top ten documents.

\begin{tabular}{|c|c|c|c|c|}
\hline Papers & DOI & Year & $\begin{array}{l}\text { Local } \\
\text { Citations }\end{array}$ & $\begin{array}{l}\text { Global } \\
\text { Citations }\end{array}$ \\
\hline $\begin{array}{l}\text { ALPEROVITS E, } \\
1977 \text {, WATER } \\
\text { RESOUR RES }\end{array}$ & 10.1029/WR013i006p00885 & 1977 & 123 & 482 \\
\hline $\begin{array}{l}\text { PRASAD TD, 2004, J } \\
\text { WATER RES PLAN } \\
\text { MAN }\end{array}$ & $\begin{array}{l}\text { 10.1061/(ASCE)0733- } \\
9496(2004) 130: 1(73)\end{array}$ & 2004 & 112 & 323 \\
\hline $\begin{array}{l}\text { SIMPSON AR, 1994, } \\
\text { J WATER RES PL- } \\
\text { ASCE }\end{array}$ & $\begin{array}{l}10.1061 /(\text { ASCE) } 0733- \\
9496(1994) 120: 4(423)\end{array}$ & 1994 & 102 & 380 \\
\hline $\begin{array}{l}\text { OSTFELD A, 2008, J } \\
\text { WATER RES PLAN } \\
\text { MAN }\end{array}$ & $\begin{array}{l}10.1061 /(\text { ASCE) } 0733- \\
9496(2008) 134: 6(556)\end{array}$ & 2008 & 98 & 299 \\
\hline $\begin{array}{l}\text { DANDY } \\
\text { GC, } 1996, \\
\text { WATER RESOUR } \\
\text { RES }\end{array}$ & $10.1029 / 95$ WR02917 & 1996 & 78 & 276 \\
\hline $\begin{array}{l}\text { ROSSMAN LA, } \\
1994 \text {, J ENVIRON } \\
\text { ENG-ASCE }\end{array}$ & $\begin{array}{l}10.1061 /(\text { ASCE) } 0733- \\
9372(1994) 120: 4(803)\end{array}$ & 1994 & 77 & 270 \\
\hline $\begin{array}{l}\text { OSTFELD A, 2004, J } \\
\text { WATER RES PLAN } \\
\text { MAN }\end{array}$ & $\begin{array}{l}10.1061 /(\text { ASCE) } 0733- \\
9496(2004) 130: 5(377)\end{array}$ & 2004 & 65 & 174 \\
\hline $\begin{array}{l}\text { MAIER HR, 2003, J } \\
\text { WATER RES PL- } \\
\text { ASCE }\end{array}$ & $\begin{array}{l}10.1061 /(\text { ASCE) } 0733- \\
9496(2003) 129: 3(200)\end{array}$ & 2003 & 58 & 287 \\
\hline $\begin{array}{ll}\text { ARAUJO } & \text { L, } 2006, \\
\text { WATER } & \text { RESOUR } \\
\text { MANAG } & \end{array}$ & $10.1007 / \mathrm{s} 11269-006-4635-3$ & 2006 & 58 & 193 \\
\hline $\begin{array}{l}\text { DOUTERELO I, } \\
\text { 2013, WATER RES }\end{array}$ & $10.1016 / \mathrm{j}$.watres.2012.09.053 & 2013 & 58 & 163 \\
\hline
\end{tabular}

Source: Authors.

\subsection{Sources analysis}

The Figure 5 below shows the evolution of publications of the journals with the highest amount of publications. One can observe a significant growth of the Journal of Water Resources Planning and Management, especially from the second half of the 1990s, being currently the journal with the highest amount of publications.

In the opposite direction, the journal by the American Water Works Association, which presented the highest productivity until the first half of the 2010s, ended up reducing its participation in the area also because of the Water Research and Water Resources Management journals. 
Figure 5 - Scientific Productivity.

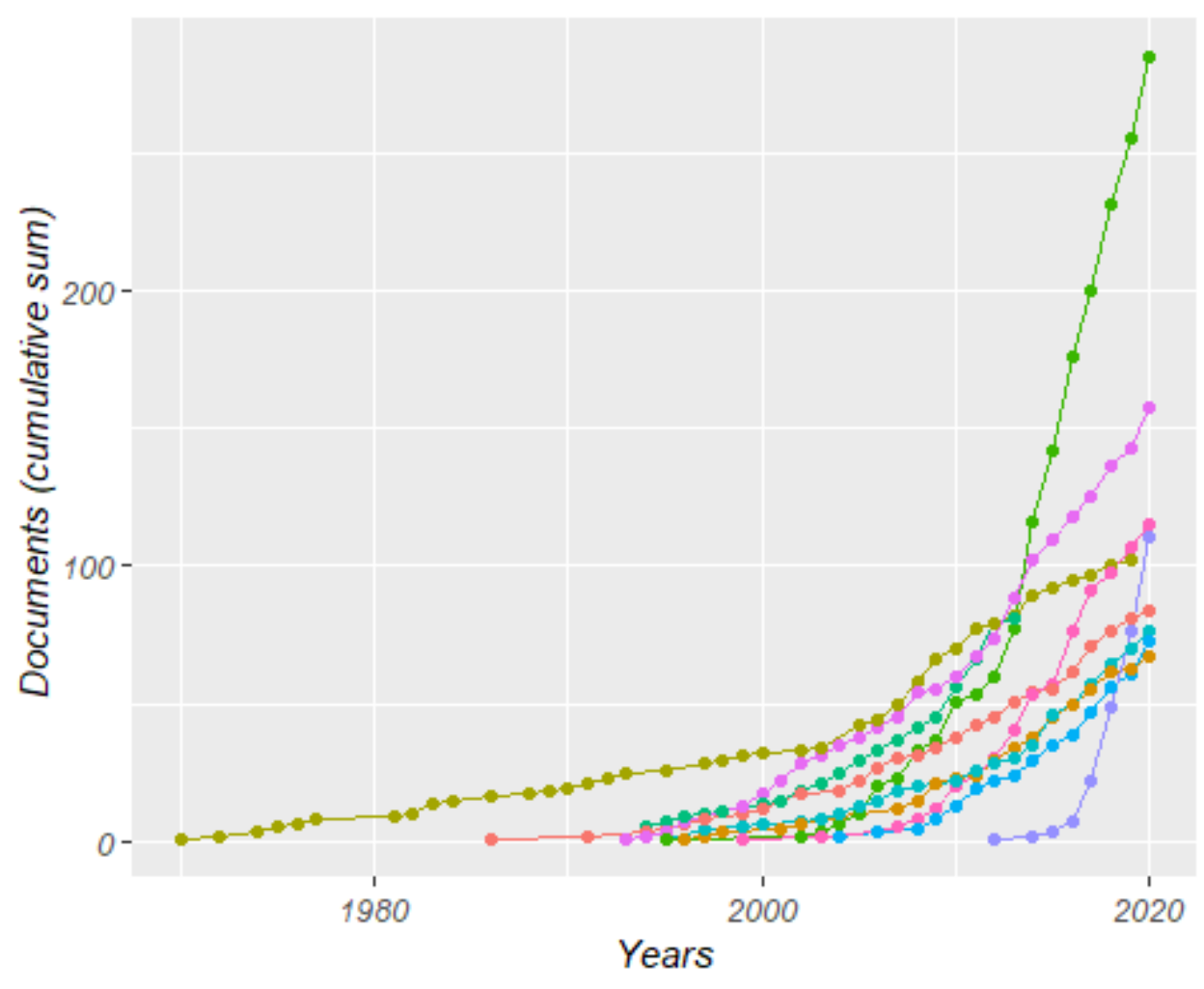

Sources

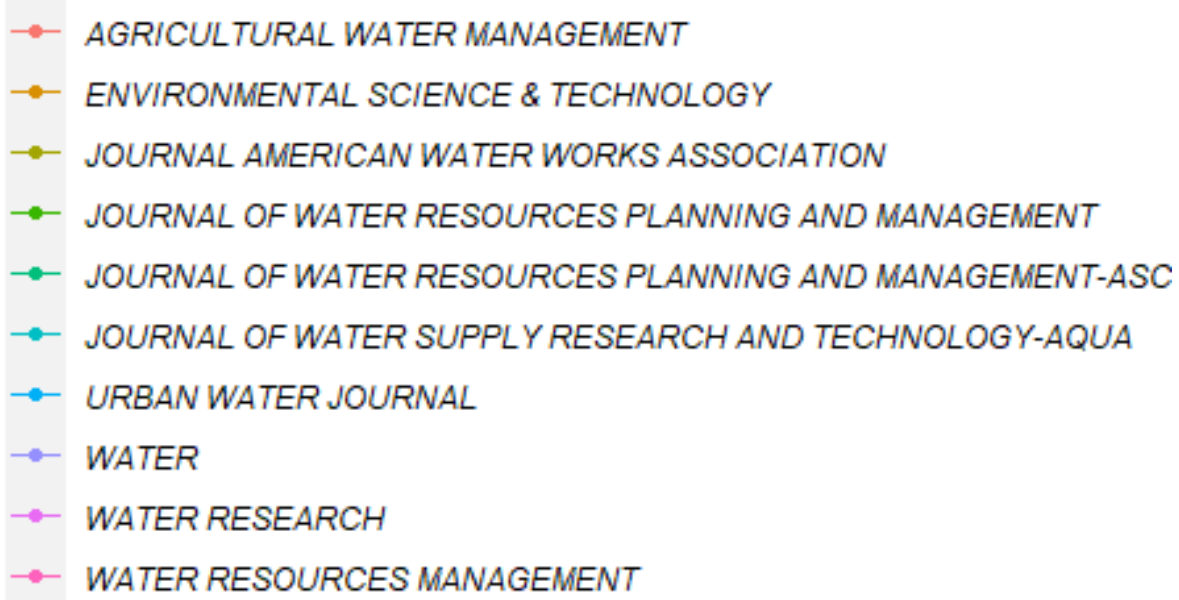

Source: Authors.

The Table 4 presents the top 10 journals, showing their h-index and the amount of published articles.

The journal by the Water Resources Planning and Management does not have the highest h-index, however, it has the largest amount of published articles and, consequently, is the most relevant among the top 10.

The journal by the Water Research has the best h-index among the 10, however, its volume of published articles is lower than the journal mentioned above and is, therefore, the second most relevant.

Analyzing the other journals presented in the Table 4, it is possible to notice that there is a significant variation between their indexes; the same happens with the two most important, however, their amounts of article publications follow a logical order and as they are the main factors analyzed here, they determine the classification of the journals mentioned. 
Table 4 - The top ten journals.

\begin{tabular}{|c|c|c|}
\hline Sources & H_Index & Documents \\
\hline $\begin{array}{l}\text { JOURNAL OF WATER RESOURCES PLANNING } \\
\text { AND MANAGEMENT }\end{array}$ & 41 & 285 \\
\hline WATER RESEARCH & 51 & 158 \\
\hline WATER RESOURCES MANAGEMENT & 26 & 115 \\
\hline WATER & 10 & 111 \\
\hline $\begin{array}{l}\text { JOURNAL AMERICAN WATER WORKS } \\
\text { ASSOCIATION }\end{array}$ & 23 & 101 \\
\hline AGRICULTURAL WATER MANAGEMENT & 28 & 84 \\
\hline $\begin{array}{l}\text { JOURNAL OF WATER RESOURCES PLANNING } \\
\text { AND MANAGEMENT-ASCE }\end{array}$ & 36 & 81 \\
\hline $\begin{array}{l}\text { JOURNAL OF WATER SUPPLY RESEARCH } \\
\text { AND TECHNOLOGY-AQUA }\end{array}$ & 11 & 76 \\
\hline URBAN WATER JOURNAL & 17 & 73 \\
\hline ENVIRONMENTAL SCIENCE \& TECHNOLOGY & 32 & 67 \\
\hline
\end{tabular}

\subsection{Affiliation analysis}

The Table 5 lists the top 10 affiliations that publish the most papers on the topic concerning water distribution networks.

The University of Adelaide, in Australia, has the highest amount of scientific output, with a total of 119 published articles, followed by the University of Exeter, in Australia, with 107 publications. The other Universities are listed and one observation has to be made. The Research on the subject of water distribution networks is being carried out all over the world, as can be seen by the affiliations listed in the top 10, with countries in Asia, Europe, America and Oceania.

Table 5 - The top ten Affiliations.

\begin{tabular}{llc}
\multicolumn{1}{c}{ Affiliations } & \multicolumn{1}{c}{ Countries } & Documents \\
\hline The University of Adelaide & Australia & 119 \\
University of Exeter & England & 107 \\
Technion - Israel Institute of Technology & Israel & 84 \\
The University of Sheffield & England & 82 \\
Polytechnic University of Valencia & Spain & 71 \\
The University of Arizona & EUA & 68 \\
Zhejiang University & China & 67 \\
Chinese Academy of Sciences & China & 53 \\
University of Toronto & Canada & 52 \\
University of Cincinnati & EUA & 49
\end{tabular}

Source: Authors.

\subsection{Countries analysis}

The Table 6 shows the 10 countries with the highest amount of published articles.

Analyzing the Table 6, it is evident the importance of research on water distribution networks. These are researches about a finite natural asset and of vital importance to human life and that is why they are developed around the world, with the American continent, being the U.S. the country with the highest amount of developed researches published. Asia also plays a prominent role with the Australian affiliations being the second largest country in volume of publications. Other countries 
around the globe also address water distribution networks in their researches, which meets the need to preserve the natural resource vital to human survival.

Table 6 - The top ten Countries.

\begin{tabular}{lc} 
Countries & Documents \\
\hline USA & 883 \\
CHINA & 403 \\
UNITED KINGDOM & 253 \\
ITALY & 231 \\
CANADA & 218 \\
SPAIN & 195 \\
AUSTRALIA & 190 \\
GERMANY & 130 \\
BRAZIL & 113 \\
ISRAEL & 103
\end{tabular}

Source: Authors.

The Figure 6 shows the documents by countries where there is more than one author per article and that can be of the SCP type, corresponding to publications in which all authors are of the same nationality and the MCP in which only one of the authors is of another nationality.

Analyzing the Figure 6, it is perceivable that the USA is the country that publishes the highest amount of articles, however, it is not the country with the highest rate of collaboration, staying behind Germany, which has the highest collaboration among the 10 countries listed and produces more articles with researchers of other nationalities.

Analyzing the dynamics of the other countries, it is evident that the publication of articles in the SCP pattern is higher than in the MCP pattern. However, research is being carried out in all continents, which becomes another form of collaboration. 


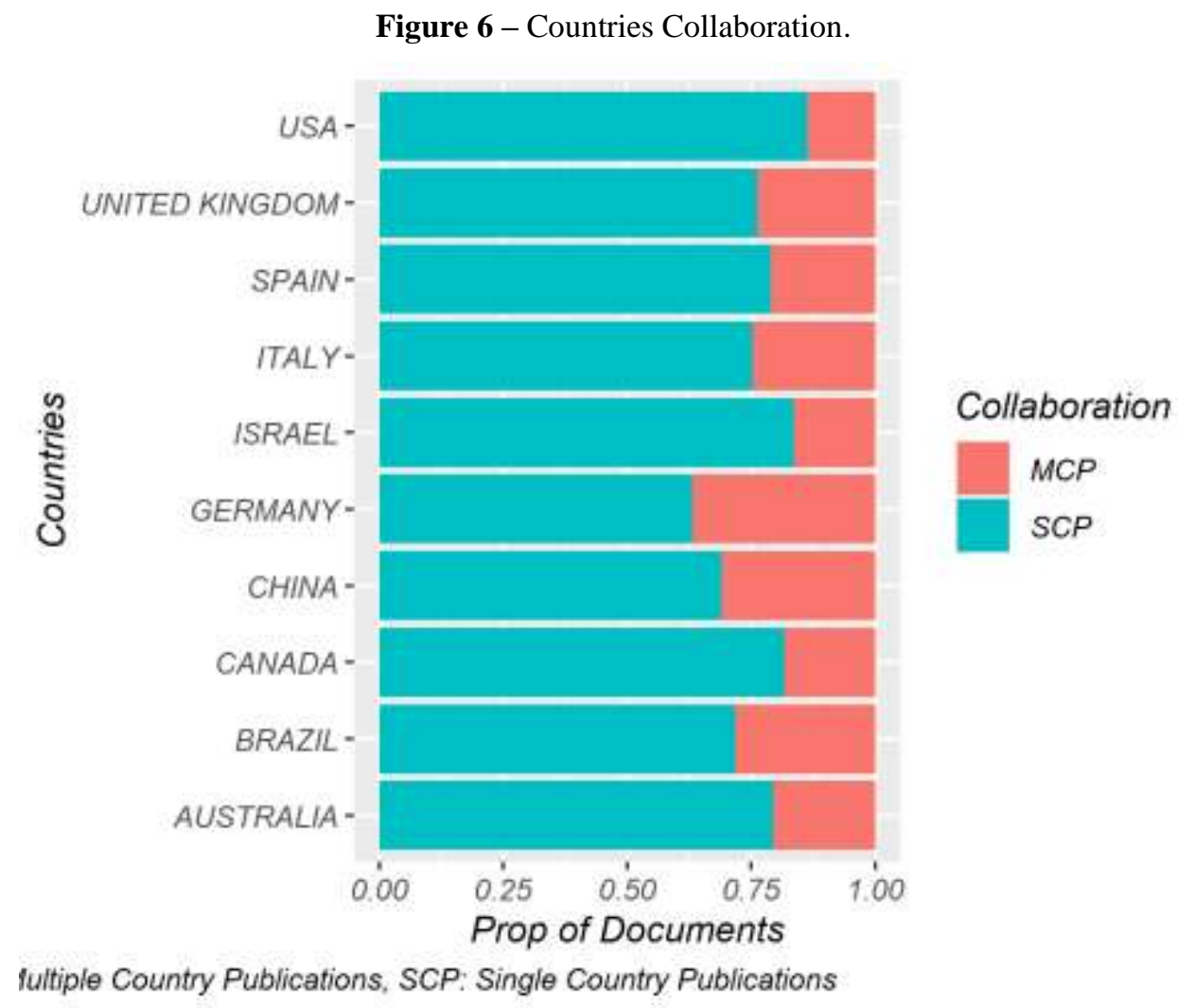

Source: Authors.

\section{Conclusion}

As mentioned before, water is a finite and vital resource for human existence, therefore, any way to avoid wasting it is of utmost importance. In this sense, the studies that approach water distribution networks are necessary.

In the present work, a bibliometric analysis was applied to the metadata obtained from the Web of Science journal database. The objective of this analysis was to point out the current state of the art, giving an overview of the research that studies water distribution networks.

The metadata obtained is composed of 4188 documents in the time span, from 1946 to 2020. It was found that, between 1946 and 1990, there was little effort denoted by research studying water distribution networks. The scenario begins to change from the early 1990s, a period in which the theme starts to gain greater proportions of conducted research, however, it is worth mentioning that even with a growing scientific production the theme still shows a low average of citations of articles per year, indicating that more research that study the theme needs to be conducted.

Geographically, it was found that research on the theme studied here is being conducted all over the world, and the most relevant affiliations are not in the same continent, which again indicates the diffusion of the theme around the world. As well as the affiliations, the authors are also of different nationalities, being from countries such as Israel, Australia, the United Kingdom, Canada, and other countries, consolidating the importance of the subject. The journals are also from countries from different continents, thus corroborating the fact that the subject of water distribution networks is of the utmost importance and common sense.

The bibliometric analysis also addressed the relevance of the themes that focus on water distribution networks, pointing out matters that begin to fall into disuse and themes that begin to emerge and are consolidating as denser and more central ones. 
It can be concluded, after the results obtained, that a bibliometric analysis is an important tool to obtain the state of the art. With it, it is possible to have a better understanding of the current situation in the development of research, making researchers more familiarized with what is most current and relevant.

\section{Suggestions for future works}

- Perform bibliometric analysis with data from more journals queries;

- Perform a bibliometric analysis only with articles in portuguese and compare their indexes with those articles in english;

- Conduct a systematic review with the effectiveness of applied statistical models;

- Conduct a quantitative survey of how many surveys developed in real networks were actually applicated.

\section{Acknowledgments}

The Federal University of Itajuba for supporting and providing ways for its employees to grow professionally.

I am grateful to the project REDECOPE FINEPE - MCT (ref.0983/10) - Ministry of science ana technology entitled “development of efficient technologies in water supply systems". I am grateful to the FAPEMIG mining researcher program for PPM - 00755-16 and to NUMMARH - Model for simulation in environment and water resources at UNIFEI.

\section{References}

Alperovits, E., \& Shamir, U. (1977). Design of optimal water distribution systems. Water resources research. 13(6), 885-900, 10.1029/WR013I006P00885

Araujo, L. S., Ramos, H., \& Coelho, S. T. (2006). Pressure control for leakage minimisation in water distribution systems management. Water resources management, 133-149, 10.1007/s11269-006-4635-3

Aria, M., \& Cuccurullo, C. (2017). Bibliometrix: An R-tool for comprehensive science mapping analysis. Journal of informetrics. 11(4), 959-975, 10.1016/j.joi.2017.08.007

Cobo, M. J. et al. (2011). An approach for detecting, quantifying, and visualizing the evolution of a research field: A practical application to the fuzzy sets theory field. Journal of Informetrics. 5(11), 146-166, 10.1016/j.joi.2010.10.002

Dandy, G. C., Simpson, A. R., \& Murphy, L. J. (1996). An improved genetic algorithm for pipe network optimization. Water resources research. 32(2), 449458, 10.1029/95WR02917

Douterelo, I., Sharpe, R. L., \& Boxall, J. B. (2013). Influence of hydraulic regimes on bacterial community structured and composition in na experimental drinking water distribution system. Water research. 47(2), 503-516, 10.1016/j.watres.2012.09.053

Hirsch, J. E. (2005). An index to quantify an individual's scientific research output. Proceedings of the National Academy of Sciences of the United States of America. 102(46), 10.1073/pnas.0507655102

Kerwin, S., \& Adey, B. T. (2020) Optimal intervention planning: A bottom-up approach to renewing aging water infrastructure. Journal of water resources planning and management, 146(7), 10.1061/(ASCE)WR.1943-5452.0001217

Liu, J., \& Lansey, K. E. (2020). Multiphase DMA design methodology based on graph theory and many-objective optimization. Journal of water resources planning and management, 146(8), 10.1061/(ASCE)WR.1943-5452.0001267

Lotka, A. J. (1926). The frequency distribution of scientific productivity. Journal of the Washington academy of sciences, 16(12), 317-323. https://www.jstor.org/stable/24529203

Maier, H. R. et al. (2003). Ant Colony Optimization for Design of Water Distribution Systems. Journal of water resources planning and management, 129(3), 10.1061/(ASCE)0733-9496(2003)129:3(200)

Ostfeld, A., \& Elad, S. (2004). Optimal layout of early warning detection stations for water distribution systems security. Journal of water resources planning and management, 130(5), 377-385, 10.1061/(ASCE)0733-9496(2004)130:5(377)

Ostfeld, A. et al. (2007). The battle of the water sensor networks (BWSN): A design challenge for engineers and algorithms. Journal of water resources planning and management, 134(6), 556-569, 10.1061/(ASCE)0733-9496(2008)134:6(556)

Prasad, T., \& Park, N. (2004). Multiobjective genetic algorithms for design of water distribution networks. Journal of water resources planning and management, 130(1), 73-82, 10.1061/(ASCE)0733-9496(2004)130:1(73) 
Research, Society and Development, v. 10, n. 12, e407101220659, 2021

(CC BY 4.0) | ISSN 2525-3409 | DOI: http://dx.doi.org/10.33448/rsd-v10i12.20659

Rossman, L. A., Clark, R. M., \& Grayman, W. M. (1994). Modeling chlorine residuals in drinking-water distribution systems. Journal of environmental engineering, 120(4), 10.1061/(ASCE)0733-9372(1994)120:4(803)

Shamseer, L. et al. (2015). Preferred reporting items for systematic review and meta-analysis protocols (PRISMA-P) 2015: Elaboration and explanation. Research methods \& reporting, https://doi.org/10.1136/bmj.g7647

Shekofteh, M. R. et al. (2020). Theoretical idea for identification of leakage areas in virtual district metered areas of water distribution networks using the artificial neural network. Water resources research, 16(3), 47-62. https://www.sid.ir/EN/JOURNAL/VIEWPAPER.ASPX?ID=831357

Simpson, A. R., Dandy, G. C., \& Murphy, L. J. (1994). Genetic algorithms compared to other techniques for pipe optimization. Journal of water resources planning and management, 120(4), 10.1061/(ASCE)0733-9496(1994)120:4(423)

Wickham, H. (2021). A fast, consistent tool for working with data frame like objects, both in memory and out of memory. https://cran.rproject.org/web/packages/dplyr/index.html 